\title{
Study on the Career Planning of College Students in Ethnic Colleges
}

\author{
Guangfen He
}

Sichuan Institude for Nationalities University, Sichuan, 626001

Keywords: national colleges, career planning, college students, problems and countermeasures

\begin{abstract}
Through the current situation of college students' career planning, this paper analyzes the reasons for the existence of this situation, finds out the problems affecting the career planning of college students in higher education, and provides countermeasures to further help the career planning of college students.
\end{abstract}

\section{Introduction}

Career planning refers to the expectation and plan for the successive processes of a person's life in a lifetime. Based on the measurement, analysis and research of the subjective and objective conditions of an individual's career planning, the final career development goals are determined and selected. The occupation or position to achieve this goal, the preparation of corresponding work education and training programs, and the development of basic measures 1 . At present, the employment of college students has been self-employed and encouraged by the planned economic system. The employment guidance of college students has also evolved from early employment policy consultation and dispatch services to today's career counseling and counseling. 2 For the future employment and entrepreneurship of college students, it is necessary to make a scientific and reasonable plan for the career of college students. However, although many national Colleges have made certain requirements for career courses in accordance with national regulations, there are still many unreasonable places in the career planning of students. This article takes the meaning of career planning and the career of national Colleges. Planning some problems and countermeasures to put forward some views.

\section{The Significance of Career Planning and Design}

With the expansion of Colleges, the employment situation of students is becoming more and more severe, and the pressure is getting bigger and bigger. At present, students of higher nationalities and universities have blind choices in employment, and there is no long-term planning. These factors restrict ethnic Colleges. The long-term development of students also has a very negative impact on the employment of students in ethnic colleges. Therefore, early career planning for students can enable college students to fully understand themselves, understand their employment and career direction, and achieve the best match. .

At present, students are under great pressure to compete in employment. If they do not seriously plan and develop themselves, they will only be eliminated among many competitors. Therefore, only by carefully doing their own career planning and putting them into practice can they be obtained among many competitors. The ultimate victory.

\section{Problems of Career Planning in Ethnic Colleges}

At present, some ethnic college students have a lack of understanding of their majors. They don't know what they can do in the future. Whether this major is suitable for them or not, blindly choose, many students see which professions in the society are hot, better employment, go The choice is not to make choices based on their own actual situation, resulting in the inability to find employment after graduation.

In ethnic Colleges, some students think that planning is useless to me. I choose to work in my 
career based on my own feelings. Because he thinks the plan is not as good as change, even some students start their careers before they graduate. Planning, these practices will lead to blind choice of career.

Each student's hobbies and interests are different, but due to various reasons, the national college students lack individualized guidance, which is very unfavorable for students' employment and entrepreneurship.

The career course is a very practical and theoretical course. To get a good job in this course, you must have professional training, and you must obtain the qualification certificate of the professional instructor. However, the teachers in the minority Colleges are mostly departmental. The department counselor or department secretary served, and most of the teachers in this part did not participate in the training, and there were not many teachers who obtained the professional instructor certificate. Therefore, the career guidance service will not play a role in helping students to find employment, and the future career education of students is not forward-looking.

Professional knowledge is the foundation of career development, but the professional skills and interpersonal communication skills required in a career need to be tested and continuously improved through practice. 3 Although ethnic Colleges arrange students to practice one semester in the last year of graduation, and arrange three activities in the other semester, such as traineeship, trainee, summer practice, etc., but the time is very short, and only some people participate, so most students Lack of professional practice. This will lead to an unhealthy mentality in student employment.

\section{Strategies for Career Planning in Ethnic Colleges}

By learning career planning, students will understand that the majors they have learned will have a clear and scientific plan for their future, so that they will take less detours on the road to employment and entrepreneurship, reduce the thorns in the advancement, and realize their ideals of life as soon as possible.

First of all, students should understand that career planning can help to improve their overall quality, avoid blindness and passiveness in learning, and plan for careers. It can also make career goals and implementation strategies at a glance, and facilitate macroscopically. Adjusting and controlling, you can make yourself less detours in career exploration and development, save a lot of time and energy; also understand that career planning can also motivate yourself, understand that career activities will accompany most of your life, have success A career can achieve a perfect life. Therefore, career planning is of particular importance.

Different students, personality, ability and many other aspects have serious differences. Therefore, career planning is not very helpful to students. Only when different students are given different personalized guidance can they play a certain role in student career planning, because professional planning is highly specialized, especially personalized career planning. , many other supporting methods are needed. Such as compulsory courses, elective courses, various lectures, social practice, internships, contests, forums, etc.

National Colleges must do a good job in the career planning of students, and they must have full-time introduction of practical work experience. Teachers who have high insight and sensitivity to today's fierce market competition can engage in career teaching. At the same time, they can also hire successful outsiders such as corporate executives. Excellent alumni go to the school to give students special lectures on employment and entrepreneurship, as well as regular professional training for career teachers, and to conduct field surveys with famous enterprises and other units to understand the talents needed in today's market, so that they have the necessary operational knowledge in teaching.

\section{Establish a Professional Practice Base}

Ethnic Colleges can use enterprises, schools, etc. to establish long-term cooperative practice bases, so that students have enough time and space to practice at the base, improve their practical 
ability and innovative ability, and lay a solid foundation for entrepreneurship and employment for future employment and entrepreneurship.

\section{References}

[1] Employment and entrepreneurship success. Editor-in-Chief Jiang Junwen Jiang Chao Chengdu Times Publishing House

[2] China Geological Education 2007 No. 299 pages Preliminary study on the construction of career planning courses in Colleges in the western region

[3] Heilongjiang Education Zhang Liqiong Higher Education Research and Evaluation 2011 No. 5 